\title{
Thomas and Barth in Convergence on Romans 1
}

By: Eugene F. Rogers, Jr.

This is the accepted version of the following article:

Rogers, E.F. (1996). Thomas and Barth in Convergence on Romans 1?. Modern Theology, 12(1), 57-84.,

which has been published in final form at http://dx.doi.org/10.1111/j.14680025.1996.tb00080.x .

\begin{abstract}
***(C) Wiley. Reprinted with permission. No further reproduction is authorized without written permission from Wiley. This version of the document is not the version of record. Figures and/or pictures may be missing from this format of the document. $* * *$
\end{abstract}

\begin{abstract}
:
This article summarizes research on the natural knowledge of God and the construal of sacred doctrine in question one of the Summa Theologiae and chapter 1 of Thomas's Romans commentary, with a comparison to Karl Barth. It takes as its challenge and motivation to uncover some of the affinities (indeed, to create a convergence) between Karl Barth and Thomas Aquinas just where both modern Barthians and modern Thomists would have thought convergence least likely: on the natural knowledge of God. It seeks to do so on the basis of their reading of Romans 1:20 in Barth's Shorter Commenta and Thomas's Super epistolam S. Pauli ad Romanos? where each of them ends up saying surprising things about the natural knowledge of God under the pressure of following Paul. Part II of the article simply asserts the reading of Thomas on Romans and takes theologian's licence to do so in theses defended elsewhere. Part III makes the comparison of the two commentaries (Barth's and Thomas's), arguing a convergence, and it too concludes in theses. Some readers may find the procedure circular. If so, I can only hope the circle is attractive enough to make them curious enough to seek more information. Part of what I hope to do is provide a reading of Thomas's theological procedure that resembles in a smaller way Barth's account of Anselm's.
\end{abstract}

Keywords: Theology | Christianity | Thomas Aquinas | Biblical interpretation | Karl Barth | Bible | Romans | God | Omniscience

Article:

\section{Introduction}

This article summarizes research on the natural knowledge of God and the construal of sacred doctrine in question one of the Summa Theologiae and chapter 1 of Thomas's Romans commentary, with a comparison to Karl Barth. ${ }^{1}$ It takes as its challenge and motivation to 
uncover some of the affinities (indeed, to create a convergence) between Karl Barth and Thomas Aquinas just where both modern Barthians and modern Thomists would have thought convergence least likely: on the natural knowledge of God. It seeks to do so on the basis of their reading of Romans 1:20 in Barth's Shorter Commentary ${ }^{2}$ and Thomas's Super epistolam S. Pauli ad Romanos? where each of them ends up saying surprising things about the natural knowledge of God under the pressure of following Paul. ${ }^{4}$ Part II of the article simply asserts the reading of Thomas on Romans and takes theologian's licence to do so in theses defended elsewhere. ${ }^{5}$ Part III makes the comparison of the two commentaries (Barth's and Thomas's), arguing a convergence, and it too concludes in theses. ${ }^{6}$ Some readers may find the procedure circular. If so, I can only hope the circle is attractive enough to make them curious enough to seek more information. Part of what I hope to do is provide a reading of Thomas's theological procedure that resembles in a smaller way Barth's account of Anselm's. ${ }^{7}$

Such a reading is significant because Barth is at once the most intrepid recent defender of the sort of scripturalism that I believe Thomas to share, and a most confident detractor of Thomas on the grounds that Thomas deserts that scripturalism for the natural theology Barth abhors. To the extent that I can defend the suggestion, made occasionally by Michel Corbin, of a convergence rather than an opposition between Thomas and Barth, ${ }^{8} 1$ will have helped to change the terms of the debate.

The clash is promising. The Five Ways of Summa theologiae 1.2.3, arguments in favor of the proposition "God exists," have constituted for a millennium the now celebrated now notorious now controverted now all-too-plain climax of natural theology. ${ }^{9}$ Barth sums up one evaluation of them as follows:

Natural theology was able,... after the rediscovery of Aristotle, to get the upper hand over medieval theology, which at last and finally became apparent in the formulas of the First Vatican Council (in the canonization of Thomas Aquinas as its supreme achievement [Spitzenleistung]).

Since the comment comes in the midst of a portrait of natural theology as dogmatics' most virulent disease, wherein the castigation of the analogia entis as "the invention of the Antichrist" has been repeated only a few pages earlier, ${ }^{11}$ Barth's characterization of Thomas's achievement as a "Spitzenleistung" becomes a superlative of disapprobation. The summit reached becomes that of a tower of Babel.

Yet where something very like the natural theology of the Five Ways appears in the Super epístolas Sancii Pauli ad Romanos lectura, it cannot be functioning as a Spitzenleistung of any sort of natural theology of which Barth could disapprove. In a letter at the end of his life, Barth writes: "On the contrary, I would gladly concede that nature does objectively offer a proof of God, though the human being overlooks or misunderstands it. Yet I would not venture to say the same of natural science, whether ancient or modern." ${ }^{12}$ If that is the division, then Thomas's arguments belong on the side of "nature" rather than on the side of "natural science," because for 
Thomas, concrete nature is already shot through with grace, and Barth's notions of science, both ancient and modern, are held captive to modern notions of a natural science that defines itself as immanent to this world. But when Thomas defines natural science in his commentary on the Prologue to John, it comes under sacred doctrine, serves the doctrine of creation, and remains open to the explication of the world as having a source and an intelligibility that transcend it. "Natural science," he writes, "considers things as proceeding from God." ${ }^{13}$ Obviously that is not the sort of "natural science" Barth had in mind. And in Barth's own Shorter Commentary on Romans (which Barth intends to match the account in the Dogmatics and enjoys the advantages of brevity and verse-by-verse organization), an explicit openness to natural theology appears which, however narrow and hedged, only leaves a space for the sort of natural theology that Thomas offers. It is indeed for just that hedged and narrow open space, with just such conditions as those on which Barth places the emphasis, that Thomas offers a natural theology—one that looks to twentieth-century eyes more like a theology of revelation. For it is objectively trinitarian, and it requires faith to be effective.

When Barth arrives in his commentary at Romans 1:20, he finds himself compelled to admit, with caveats and reversals, that

the world which has always been around [the Gentiles], has always been God's work and as such God's witness to himself. Objectively the Gentiles have always had the opportunity of knowing God, his invisible being, his eternal power and godhead. And again, objectively speaking, they have always known him. In all that they have known otherwise, God as the Creator of all things has always been objectively speaking the proper and real object of their knowledge, exactly in the same sense as undoubtedly the Jews in their law were objectively dealing with God's revelation. ${ }^{1}$

In some ways that statement sounds as if it goes far beyond what Thomas would say. Barth does not distinguish God's essence where Thomas would, for example. In other ways, Barth's attempt to qualify his claim by dialectic rather than distinction will cause him to seem to take it back.

The discipline of having to follow Paul (within, to be sure, a certain very broad tradition of interpretation which they themselves help to define) will make each of them, Barth and Thomas, model his presentation of certain issues in natural theology less upon his own situation and preferences than he does in his more systematic works, and more, instead, upon the perceived moves of Paul. That presentation will in turn render more visible theological similarities of argument, agenda, and approach that situations and circumstances might otherwise becloud. Barth and Thomas will each seek to execute what we may call the "material moves of Paul."15 Thus by "material convergence" I mean in this case just such a pattern of argument as Paul executes first and Barth and Thomas follow, as it were, at a distance. ${ }^{16}$

I seek to discern a common underlying pattern just when differences of vocabulary, emphasis, and time threaten to cover it. Under the influence of Paul their common teacher, Thomas will 
talk about the ineffectiveness of natural knowledge of God under certain sinful conditions and how it serves to prove the necessity and sufficiency of grace, conditions that go unmen-tioned in the tightly circumscribed article on the Five Ways; under the same influence Barth will talk about the possibility of an objective natural knowledge of God, a possibility that goes unmentioned in the differently directed polemic of Church Dogmatics 1,2 and 11,1, except to seem denied. Each must intentionally or unintentionally press his own questions upon Romans, but Romans will in turn with greater or lesser influence press its questions upon each one. It is by attending to the latter pressure - that of Romans, or of a tradition of reading it, upon its commentators ${ }^{17}$ — that I hope to discern a convergence in the matter of natural theology. Natural theology as a Christian discipline finds its home, both Barth and Thomas would agree, in Romans 1. Indeed even Thomas deploys the phrase "theologia naturalis" there, in one out of two places, and the connotations are every bit as negative, even if his opponents are inevitably different and his tone characteristically milder. ${ }^{18}$

Specifically, I am aiming for the scriptural warrant for the Five Ways. For if there is one place in the Summa where the skeptic sees Thomas's script-uralism in retreat, it is in the Five Ways. Generations of students have passed over question one (the nature of sacred doctrine) to give pride of place to question two (the existence of its object). In so doing they neatly if unwittingly substitute the logic of coming to believe for the logic of belief, ${ }^{19}$ which question one has specified. It is question two read as if in isolation that functions to define the scientific character of Thomas's theology, and it is a very different scientific character from the one I will argue is to be found in question one. Gilson for example regards it as "extremely important" that those things that are "purely rational" in Christian beliefs "can be extracted from their theological context and judged, from the point of view of natural reason, as purely philosophical conclusions." Furthermore, that "enables us to understand how strictly metaphysical knowledge can be included in a theological structure without losing its purely philosophical nature." ${ }^{20}$ Such a reading provides an immediate challenge to readings like mine (including those of Corbin and Preller). For one might find the criterion of consistency reversible. One might argue, that is, that a certain other reading of question two tells us what Thomas's "real" intention is, and that question one ought to be read so as to cohere with that, instead of the other way around. It is one purpose of the theses that occupy Part II to make readings like mine more nearly irreversible by putting question two into its scriptural context.

The symmetry is striking: Thomas's warrant for the Five Ways (precisely: for the demonstrability of God's existence at 1.2.2) is Romans 1:20, and in Thomas's Romans commentary-Super epistolam Sancì Pauli ad Romanos lectura - at 1:20 there appear similar cosmological arguments. ${ }^{21}$ If we put the commentary on Romans, chapter one, verses nineteen to twenty-one, into context, we will have put Thomas's natural theology into context, even in its most prominent form. If scripturalist considerations control the claims for the natural knowledge of God in the commentary where it is at home, and we take seriously the instructions of the Summa's prologue to read it as a compendium and abbreviation of matters that arise in commentary on scripture, ${ }^{22}$ 
then they also control the claims for the natural knowledge of God in question two, and the burden of proof becomes much heavier upon the nonscripturalist reading.

\section{Conclusions About the Natural Cognition of God From Thomas's Romans Commentary}

1. There is in Thomas's Romans commentary a paradigmatic use of the natural cognition of God which occurs with fiducial faith ${ }^{23}$ in the context of

justice, piety, gratitude, and finally the infused grace of charity. ${ }^{24}$ This is the cognition of God that sacred doctrine uses and turns into wine.

2. There is a defective use of the natural cognition of God which occurs without faith in the context of injustice, impiety, ingratitude, and finally the direction of the will away from God. This is the cognition of God that every concrete, existing Gentile ${ }^{25}$ seems to have according to the Romans commentary, the cognition of God that cries out for the grace of the gospel (In Rom. 1:166, \#97) of Jesus Christ (\#102). ${ }^{26}$ Otherwise it is wine into vinegar.

Is there no third, neutral use?

3. The Enlightenment imagines neutral human beings, neither delivered up to injustice, impiety, and ingratitude, nor religious enthusiasts; it imagines human beings who disengage their wills from their knowing. Thomas does mention human beings "with no will to believe except on the basis of proof" (ST II-II.2.10 ad 1). Even the love of truth, however, is a movement of the will toward the good. Having no will to believe can, for Thomas, only reflect a flight from the good, an aversion of desire from it. Those rational creatures with no will to believe except on the basis of proof whom Thomas accords more than a mention are already those with no will to believe even in the face of proof. Those who wait upon intellectual coercion, until they are "in some way driven [coacta] by the evidence" are the demons who believe and tremble (II.II.5.2. ad 1). Even those who debate with infideles "not supposing the truth of the faith as certain," or "as //"doubting" commit a sin, although to do so for refuting errors (to the opponent's good) or as practice (to the good of the debating believer who lets herself be corrected), is laudable (IIII.10.7c and ad 3).

4. But does Thomas not in fact mount just such a neutral project in the Summa contra gentiles? If Michel Corbin is right, the answer is yes and no. ${ }^{27}$ Thomas mounts some such project, but he leaves it uncompleted. He changes course mid-work. Either he cannot carry it through, or he intended merely to adopt the pose of neutrality, switching later to a conceptuality incompatible with neutrality, and anticipates that of the Summa, which exemplifies the first, paradigmatic use of the natural knowledge of God. It is neither irrational nor cynical to pursue the latter course. Thomas does not take up the pose of the sincere doubter, so as to deceive readers about his commitments, but takes up a temporary position, as a teacher, which he will pull up from behind him like a used ladder. Thomas begins in the Summa contra gentiles with a strategic and temporary, self-consuming division of the truth into two modes. When he moves them toward 
coherence, however, he moves the use of the natural cognition of God away from neutrality toward the use that obtains under the conditions of faith. In so doing he mimics in the academic presentation of theology what happens in the life of a convert. The coherence of a life is able to be constructed only in retrospect. Similarly the penultimate (this-worldly) coherence possible for arguments asserting the proposition "God exists" comes only within sacred doctrine. Thomas merely begins with a fragment that looks quite different in its final context. Either we must say that the Summa contra gentiles executes its transition to another genre as an intentional rhetorical trope, one that seeks not to trick but to sublate, and deliberately turns water into wine; or we must say that Thomas allows the project of the Contra gentiles to fall into a category mistake. If we allow Thomas the charity of the first interpretation, we will see that the awkwardness of the transition comes from its prospective arrangement: in retrospect it makes sense. The miracle of water into wine makes sense, after all, only after the fact, when it forms part of a gospel narrative that seeks to tell the story of Jesus. From the standpoint of the water, if you like, the transition to wine is entirely opaque.

The Enlightenment and its neo-Thomist critics mistook the project of the beginning of the Summa contra gentiles for something that controlled the interpretation of Thomas's entire corpus, including the Summa theologiae, because it seemed to accord well with their own project. Perhaps it was all but inevitable that they should do so. But that Summa belongs to a manifestly different genre from that of the beginning (at least) of the Contra gentiles.

5. The discussion of the natural knowledge of God in its integral form - as objectively trinitarian $^{28}$ and as issuing effectively in justice, piety, and gratitude-represents nature as completed and perfected by grace. Under conditions of sin, the completion and perfection of nature by grace involve the redemption that comes to the faithful.

Some background is in order for a claim about the much controverted relation of nature and grace. I follow Otto Pesch. Adam was created with nature and, out of God's superabundant mercies, in grace (ST 1.95.1), or in a state of "original justice" (1.100.1). Grace was not constitutive of nature, any more than standing upright is constitutive of a human body; but being stood upright was both a good o/the body and a gift to the body, the loss of which could not be restored by the body itself. As Pesch puts it: "Original righteousness is a good of nature, in that it neither altered nor added to its constituents; it is a 'supernatural/ 'gracious' gift to nature, because it cannot be made available by nature's own power." ${ }^{29}$ Like life itself (strictly, in terms of God's gift of a soul), it could be passed on, but not recovered once lost. ${ }^{30}$ Pesch comes to a careful conclusion. The "essence" of original sin "does not consist, like actual sins, in the loss of grace ..., but in the loss of the due harmony of nature [granted, a harmony worked by supernatural gift]. Fallen nature is sinful not because it has no grace, but because it is unready — 'indisposed'-for grace." ${ }^{31}$ Likewise bodies once dead decay and are shortly no longer disposed for life (or a soul). The result is that Thomas knows no cases of pure nature, neither ungraced nor Unfällen, just as we know no cases of abstract bodies, in some state of suspended readiness for life, neither alive nor undecayed. Although both abstract nature and unsouled bodies are logical possibilities, the 
real possibilities are nature graced or failed, bodies living or decaying. If I am right about Thomas's contrast, then it shows up

in the Romans commentary when he uses Paul's later life as an example of nature in good working order, nature under grace, an example to which he devotes the Prologue to his commentary on the epistles, and when he uses Paul's Gentiles as an example of nature manqué. ${ }^{32}$

6. Cognitio naturalis is always and everywhere cognitio naturalis gratia evangelica Christi (my phrase in Thomas's words; cf. \#97, 102:) namely natural cognition by the grace of the gospel of Christ: for without the grace of Christ working in advance we would have died outside Eden. But it comes in two forms: "detained" and redeemed. ${ }^{33}$

At ST I-II.109.1 Thomas affirms that a human being can have a cognition of something true without grace: This does not deny that a human being still lives and knows by the grace of creation, but it affirms that some knowledge is possible without the grace of elevation. ${ }^{34}$ The two are one grace, one plan of God, broken in its execution by human sin.

Concrete or alloyed (as opposed to pure) nature in this plan of God's (as opposed to some other possible plan that God did not choose) is nothing other than the grace of elevation working in advance, proleptically, under conditions of sin, to keep us alive and functioning until God's plan proceeds; it is not a human power so much as a divine mercy, no less so if we fail to recognize it as such. As a mercy under conditions of sin it is already not only God's elevating grace persisting because of God's remaining true to God's own purpose and promise; it is already God's saving grace. Otto Pesch puts it this way:

It is easy to overlook: the justification of the sinner is no "new" dispensation of God's, but the carrying out of God's creatorly will over against the rebellious human creature. The dimensions of nature that remain undisturbed are therefore to be conceived of as the effectiveness already in advance |Vorauswirksamkeit| of the grace that saves. ${ }^{35}$

So nature is a cross-section of God's plan. We misunderstand it if we consider it on its own. We must take the viewpoint of the whole, whether from creation forward, or from the eschaton back. From creation forward we see concrete nature as the persistence (in the face of obstacles) of God's gracious plan to take us beyond ourselves to be God's friends. From the eschaton back we see concrete nature as the anticipation (despite obstacles) of that same plan. It would be odd (if not violent) for God to befriend us without respect for our temporal condition; therefore we must not be surprised if God's purpose of befriending us has temporal, and to us in time therefore anticipatory effects. Glory follows grace just as what is first in intention is last in execution. After the fall, nature can be understood only in terms of what lies before and after it. Nature, under conditions of original justice granted and lost, is God's not foreclosing on the plan of creation, and God's not preventing the anticipation of elevation, or a place for the plan to be carried out, and the execution to begin. 
Thus Thomas's affirmation of cognition "without grace" praises the persistence of God's intention even before its execution. It does not set human knowing apart from God. It affirms what we may call cognüio naturalis detenta. Thomas's affirmation does a knowledge that denies the glory of God, and fails to issue in gratitude, the courtesy of calling it by what it has been and might be. In calling it in virtue of what it has been, the affirmation accuses it of failure, and recalls it to its vocation. In so doing, the affirmation refuses to deny the cognition to the intellect, just so that it can assign the subtraction to the will.

We Gentiles have "subtracted from God's knowledge" \{In Rom. 1:21, \#127) as we have rejected God's aid, so that our knowledge fails to form us as our nature fails to hold us upright. Through injustice and ingratitude we confine ourselves to cognitio Dei subtracta, that is, a cognition of God without the ramifications or the full coherence that faith requires, without fiducia (\#129). That is because we have been "a scientia Dei subtrahentes," (\#127), i.e., holders of a cognoscitive habit without the deeds and attitudes of charity (In Rom. 1:17, \#\#105-108), like the justice, gratitude, and piety here mentioned. Without those Godward and God-given attitudes like those Thomas finds in Paul (Prologue, \#\#1-3), we lose too the cognition's objective trinitarian coherence.

For convenience we can invent technical terms that imitate or keep close to Thomas's language. Call the defective form "cognitio detenta," after the Pauline phrase "they detained the truth in unrighteousness" of Rom. 1:18 (cf. \#\#111-112,127-130); or "cognitio subtracta," since it results from subtracting from or insulting the power and scientia that God possesses, on which it should depend (cf. \#127). Call the full form "cognitio iustitia formata," to reflect the commentary's constant preoccupation with justice (occasioned by Paul's), and to show the parallel to "faith formed by love." Or call it more briefly "cognitio integra," in contrast to "detenta" or "subtracta"', or "cognitio evangelica," a phrase that appears at paragraph \#103 in explication of the "ex fide in fidem" passage, since it is the cognition of the gratia evangelica that Thomas make the theme of the entire letter (In 1:16b, \#97); or "cognitio salutifera," after the phrase at In I Cor. 1:21, \#55. Or borrow Thomas's description of what it is supposed to accomplish and call it "cognitio vera, which leads human beings to the good" (In Rom. 1:18, \#112).

7. Thomas says in the Romans commentary that we have the faith of which he speaks only under the condition of trusting God, but note that he does not exclude the possibility of also in appropriate cases trusting human reasons and natural signs; only they are "not yet" faith if they are all we trust (In Rom. 4:3, \#327; cf. ST II-II.2.2). They are precisely in that sense of "not yet" preambles. Contrary to popular belief, preambles are "pre-" not because they are foundational (in the sense of logically prior or more generally accessible), but because they are serviceable (in the sense of standing at sacred doctrine's disposal.) ${ }^{36}$ They are things that may become faith; in that sense, as possible manuduction for the faithful, they precede it; but they need not. And should they be taken up into faith, they contribute nothing to it, for faith properly so called depends upon nothing else than trusting God. Still, we can distinguish preambles from things that could not be taken up into faith, such as "God is a creature." 
The contrast between preambles and articles, within limits, is relative. Some things will never be susceptible of proof. Other things must be susceptible of proof, because the scriptures tell us so reliably. Still other things do not have that status specified. Both preambles and articles come into sacred doctrine under the conditions specified by their lying sub ratione Dei or by their status as revelabilia. That is, a verbally identical demonstration will function differently in the theology that pertains to metaphysics from the theology that pertains to sacred doctrine (1.1.1), because the context that specifies the use and therefore the meaning of the words will differ (cf. II-II.2.2 ad 3 on philosophers' use of "God"). The context proper to sacred doctrine is specified by the formal rationale of trusting God (ST 1.1.3, etc.).

The contrast between preambles and apparently demonstrated articles, or between serviceably and unserviceably demonstrated truths, however, is sharper. At 1.46.2 Thomas lists no fewer than eight apparently demonstrative arguments for the proposition that the world had a beginning instead of having always existed. Were the presence of a demonstrative argument enough, Thomas would have to consider it a preamble that the world had a beginning. But Thomas knows, as 1.1.1 has it, that even demonstrations sometimes turn out to have an "admixture of error." Therefore he does not rely upon them, but upon the Creed. What counts as preamble does not depend upon what science demonstrates: "And this is useful to consider, lest perchance anyone, presuming to demonstrate what is of faith, should adduce insufficient reasons, which would provide material for ridicule among the infidels, finding us believing for such reasons the things that are of faith." ${ }^{37}$ Since it is the creed rather than the state of metaphysics that tells Thomas what is demonstrable and what not, he goes on to find errors in each of the demonstrations. He would have had to look for errors in the Five Ways, too-and would also have found them ${ }^{38}$ - had revelation not guaranteed that some such ways would work. And the fact that most people today would not consider them to work would bother Thomas, would "provide material for ridicule" among the cultured despisers, only if Thomas's argument in 1.2.3 actually depended upon the cogency of the demonstrations. But it does not. It depends formally on trusting what God says (1.1.8), in Rom. 1:20 (1.2.2, sed contra), as 1.46.2 depends on what God says in the Creed. In both places we have apparently valid demonstrations. In both cases Thomas is prepared in principle and in advance to find the demonstrations mistaken. In both cases we nowadays tend to find them mistaken. The fact that Thomas tends to find one set mistaken and another set not has to do not with the contingent state of human learning, but with the authority of scripture, when well interpreted, to judge it (1.1.6 ad 2). Only if he judges it capable-yes in the case of whether God exists, no in the case of whether the world had a beginning - does he then use it "as an architect uses builders, a citizen a soldier" for the "easier leading by the hand" (manuductio) of our defective intellects (1.1.6 ad 2). That then is the difference between demonstrations that serve as preambles and those that do not: sacred doctrine's formal rationale tells Thomas which secular arguments overlapping with sacred doctrine's matter will prove serviceable and which not. Preambles do not prove their own serviceability; that depends on how sacred doctrine presses them into service. 
The interpretation of preambles in terms of serviceability, or in Thomas's terms, as manuductions, gives us no reason to deny that if a preamble is Aristotelianly demonstrated cognitio, then it must count in some non-equivocal sense as scientia. It counts as scientia in metaphysics, for example. And just if our use of the word "scientia" is not to equivocate, then there must be some continuity between the scientific character of preambles in metaphysics and some scientific character in sacred doctrine, even if they are strictly extraneous to it (ST 1.1.8). Otherwise scientific character fades in and out according to discipline, one sealed hermetically off from another. Then not only theology, but all sciences are fideistic. The difference between the current interpretation of the status of preambles in the Summa and other possible interpretations is that rival interpretations tend to articulate the continuity of scientific character from the bottom up. For many of them, preambles are the paradigms of demonstration which sacred doctrine must match.

According to the interpretation defended here, however, the order is reversed. The paradigm of demonstration is the "demonstration of the Father" by Jesus Christ, "who, as a human being, is the 'demonstration' [via] stretched out for us into God" (ST I, proemium to q. 2). ${ }^{39}$ According to the philosophy of science implicit in the Summa, it is other scientific disciplines that mimic that. The scientific character of other, Aristotelian demonstrations comes from the top down; to call Aristotelian and christoform arguments both "demonstrations" and both "scientific" is not equivocal, according to sacred doctrine, just because Aristotelian demonstrations too participate in the Logos by analogy. The "other" viae — the quinqué viae—do not represent the paradigm of demonstration. Rather Thomas's theological appropriation of the Five Ways saves our penultimate and provisional demonstrations from equivo-city, from not counting as demonstrations after all. The appropriation saves our cognitio subtracta, the cognition we have generally and for the most part, which was enough for Aristotle, but which Thomas relegates to the theology that belongs to metaphysics. The appropriation saves the Five Ways by taking them up into the realm of revelabilia, in which, through God-bestowed faith, they are joined with the first truth they cannot otherwise reach. The Five Ways are caused to assert the unGodforsakenness of nature under conditions short of the will's assent to God. They are caused to assert the unGod-forsakenness of nature even in conditions of a will's dissent from God. In so doing they save Paul's usage; they save cognitio subtracta. And in so doing they claim the world for the realm of revelabilia. The point is not that Aristotle is outside the realm of the revelata; he is led by the hand into the world of revelabilia.

The second form of cognitio naturalis gratia evangelica Christi is what we have been calling cognitio integra. This is what Thomas has in mind when he abbreviates the long form as "cognitio evangelica" (\#103). This paradigm form of human cognition of God comes in several forms, among them, fides. ${ }^{40}$

8. Since we have seen that the cognitio Dei functions only in the presence of grace, we know something about the conditions under which we can have an Aristotelian science whose subject is God. For an Aristotelian science requires that propositions be put in order so as to deliver 
effective knowledge - "true cognition, which leads human beings to the good" (In Rom. 1:18, \#122). For Aristotle, a science just is that structuring of propositions - as in demonstrations - to render the mind formed or structured in accord with the form or structure of reality. For sacred doctrine, Aristotelian science requires some wrenching.

For it has been the further point of Thomas's entire exposition of Romans 1 -and indeed of the eleven following chapters that will carry him to chapter 12-to explicate the necessity and sufficiency, for the integral and effective knowledge of God, of the evangelica gratia (\#97) that he ascribes to Christ. Evangelica gratia Christi, to invent a technical term, specifies the conditions under which Thomas thinks human beings can, through restoration and elevation of their natures, enjoy effective cognitio Dei. Thomas causes Aristotle's notion of a science to serve sacred doctrine and not the other way around. For Thomas has set things up so that the more scientific it is, the more sacred doctrine looks to the gospel of Christ. ${ }^{41}$ Taking the Aristotelian concept of science "captive in obedience to Christ," as ST 1.1.8 interprets II Cor. 10:5, requires the following further distinction.

9. Since Aristotle's language of scientia as of things seen and the Bible's language of faith as of things not seen (II-II.4.1) makes a division, then when the natural cognition of God becomes effective by grace, its effectiveness belongs on the side of faith, not on the side of scientia. ${ }^{42}$ For it is by faith that we are united to God (1.12.13 ad 1), and faith that motivates and structures (infuses and habituates) change in the human soul. That is the logic of Thomas's Romans Commentary.

The first question of the Summa gives the following account of that logic. ${ }^{43}$ It is not because of the account in the Summa that things go that way in the Romans commentary; it is because of the account in Paul. Like Aristotle, Thomas maintains a secondary and penultimate distinction between the structured discipline (like German Wissenschaft) and the structured habit (like German Erkenntnis) of effective cognition, and unlike Aristotle Thomas introduces, in sacred doctrine, an additional terminological distinction for two reasons. 1) The disciplined or scientific character of sacred doctrine is borrowed by revelation from the sdentici enjoyed by God and the blessed: it does not inhere in the human intellect in this life (ST 1.1.3). The work of the theory of subalternation is to claim the title "scientia" for a discipline that cannot, of its own habit, so change the soul as to save it, that cannot, in short, reach its purpose. Meanwhile (2) the habitual or soul-structuring character of the believer is not gained from studying the science of sacred doctrine, since its subject lies outside the realm of the humanly comprehensible; the habit is infused. Because sacred doctrine seeks a source of intelligibility for the world that lies outside the world, and a source of intelligibility for the mind that lies beyond its powers, its real and mental instantiations remain apart, its discipline borrowed, its habit infused. Thus Thomas must retain "scieniia" for the structuring of the discipline, in virtue of the reliability of the reality of revelation, and "fides" for the structuring of the soul, in virtue of the gratuity of salvation. The discipline deserves the title of "science" by leaning upon the science of God and the blessed (1.1.2), but the habit is denied the title of science because sacred doctrine is a science unable to 
operate by itself io structure the soul; its operating comes by faith, and even so operation is denied (by the invention of the word "cooperation") to faith, since faith is a movement of the soul by God (HI. 111.2).

So too demonstration differs in this structuring of cognition from others. Jesus Christ structures the discipline by being himself the real light, the new feature of reality, that demands a new real science; Jesus Christ (as a human being) is himself the primary demonstration in the proemium to question 2, and he is himself the primary state of affairs to which other states of affairs point forward and backward according to the theory of scripture as sacred doctrine's authority at the end of question 1 (ST 1.1.10). At the same time Jesus Christ structures the soul by dwelling within it. The intellectual counterpart of that indwelling, by which God unites us to God precisely as One unknown (1.12.13 ad 1; cf. In Rom. 1:19, \#114) is not scientia but faith. Thus even as we study the scientia of sacred doctrine we become not its scientists but its believers. Thus the necessity and sole effectiveness of the gratia evangelica Christi in the Romans commentary. The Aristotelian structure of the soul does accompany faith, and the Aristotelian structure of the discipline does belong to sacred doctrine: both arise from the same structure of reality understood as the real first principle of an Aristotelian science. And the connection therefore between the real first principle and the structures of discipline and habit that follow from it is rightly called a demonstration. But that first principle and its demonstration, both in the extramental discipline and in the intramental habit, are both Jesus Christ. Sacred doctrine assumes metaphysics into christology. ${ }^{44}$

Thomas is not kidding when he distinguishes, in the very first question of the Summa (ST 1.1.1 ad 2) the formality of the theology that belongs to metaphysics from the theology that belongs to sacred doctrine. And yet here again the appellation of Aristotelian science is justified for sacred doctrine just by reference to Jesus Christ. For only by reference to Jesus Christ does sacred doctrine keep together the structures that come together in Aristotelian episteme: the structure of reality, the structure of the academic discipline, and the structure of the soul to be formed in accord with its end and desire, in this case salvation. ${ }^{45}$

Thus it is no accident, and no expression of mere pious sentiment, that Thomas calls the humanity of Christ via and demonstratio (ST I, proemium to q. 2, and III, prologue). Those words most fittingly portray the figure of science put at sacred doctrine's disposal. They represent the language appropriate when sacred doctrine trains philosophy seriously as anelila theologiae. They do not merely turn water into wine, they make argument flesh.

\section{Ill Thomas and Barth}

In a commentary on Thomas's argument ${ }^{46} 1$ have tried to show, and in Part I of this article I have tried coherently to assert, that the natural cognition of God functions properly-that is, is able to execute cognition's proper office of shaping the soul—only in the presence of grace. Natural cognition of God without grace is an anomaly, a residual, defective "cognition," so called only by 
courtesy that proves irrelevant to salvation except negatively, in increasing human fault, in showing our cognition of God to be a has-been. Natural cognition of God without grace is a selfconsuming artifact, unnatural, denatured, a paradox. Meanwhile, the praise of the natural knowledge of God without grace that some seem to detect in talk of preambles I identified as a misreading based on taking the Contra gentiles rather than question one of the Summa as the governing text; preambles function differently, I argued, in the last stage of Thomas's development. ${ }^{47}$ They get transmuted into faith. The cosmological arguments fulfill the charge of sacred doctrine to leave no part of the world God-forsaken. The reading sought to take better account of the integrity of an Aristotelian science.

\section{A Barthian objection and Thomas's reconstructed reply}

Let us raise the stakes by pursuing the comparison with Karl Barth. Consider the following contrast between Barth and Thomas proposed by one of the most convinced and convincing Barthians, George Hunsinger. ${ }^{48}$ The recent date of his study-1991_reminds us that the reading he offers of Thomas on nature is still current. He serves as careful and interesting example of a whole class of possible critics.

By reviewing Aquinas's discussion of the justification of the unrighteous, the contrast between the two theologians [Thomas and Barth] can be sharpened. In what sense, Aquinas asks [I-II.113.10.], might this justification be considered to be a miracle? Three possible senses of miracle are distinguished. First, insofar as a miracle is something which can be done only by divine power, justification can be considered a miracle. Second, insofar as a miracle is something which actualizes a possibility not inherent in nature, justification cannot be considered a miracle. Finally, insofar as a miracle is something which operates outside the usual order of cause and effect, justification may or may not be considered a miracle, depending on the circumstances. (In case where an instantaneous conversion actualizes perfect righteousness in an individual all at once, as occurred with St. Paul, justification can be considered a miracle; otherwise, righteousness is perfected within the individual by grace as it operates inside the usual order of cause and effect.)

It is the second of these points which provides the best contrast with Barth. Barth agrees with Aquinas that the justification of the unrighteous person is something which can occur only by divine power, but disagrees that in justification (and thus in salvation) grace actualizes a possibility inherent in human nature. Barth considers justification to be a miracle in the very sense that Aquinas rules out. Indeed, Barth must do so, precisely because he disallows a key premise articulated by Aquinas in this text, namely, that 'the soul is by nature capable of or open to grace.'

But such an assumption, in Thomas, does not impugn grace but lauds it. It does not render "nature" incoherent but preserves for it the possibility of coherence, does not tie God's hands but 
bears witness to God's steadfast remaining true to God's own self, to God's creative purposes and elevating promises. It does not make grace a human creature but preserves nature as a divine mercy. Yet the standard charge is serious: "If this premise is granted as used by Aquinas, divine grace and human freedom must necessarily be conceived as interdependent in the work of salvation."

It is true to say that Thomas interdefines nature and grace. That is because we cannot understand properly functioning nature apart from grace, and we cannot recognize nature, either as it concretely subsists in the faithful or as it concretely subsists in the unfaithful, without knowing what its end is, a purpose that God graciously bestows upon it in elevating it. This much any Barthian should grant: we ought to define nature in terms of grace because it takes Jesus Christ to tell us what nature is. That is also the burden of the insistence of question one of the Summa upon the praecognitum finis, something foreknown about the human end-which is finally the humanity of Jesus Christ - as necessary for understanding nature in terms of what God has in store for it. But to say that the conception of nature depends upon grace is different from saying "divine grace and human freedom must necessarily be conceived as interdependent in the work of salvation." That would be so only if human freedom contributed something independent in the work of salvation. But that contribution is different from cooperation, precisely because cooperation is entirely dependent upon grace.

"Cooperation" language merely ensures that we do not do good wnwil-lingly. Barth too requires that we do the good "gerne/" eagerly; it does not change the point that Thomas deploys a technical term and Barth does not. If God moves the motive, that does not impugn but praises grace: "our mind both moves and is moved ... whence the entire business [operatio] belongs to grace" and not, that is, to us as opposed to grace (I-II.111.2c and ad 2). The only alternative would be a sort of nature that could not undergo movement by God without becoming something else. Protestant thinking sometimes goes that way: anything moved by God must be by grace; grace and nature are mutually exclusive categories; therefore nothing moved by God can be natural. But such a nature would be almost incomprehensible to Thomas. The sort of thing that could not undergo movement by God without becoming something else could not be a creature, which was made to be God-moved. Or natures made for God could not be moved by God as their end, so that they not only fall away from God, but escape from God into nothingness. The objection eliminates creation by making it something immovable, and such absolutes are either divine or demonic in a non-Christian way. The objection, that is, resolves creation either into the sort of non-critter that a Manichean evil would be, or into the sort of non-critter ${ }^{49}$ that God is.

For these purposes, therefore, it is misleading to abstract nature from the context of the divine plan and the concrete (supernatural) human end. Perhaps it is strictly possible to define nature apart from grace, in terms of human ordering, but given the concrete human ordering beyond itself, it is speculation of a pernicious kind, about how God might have treated us if God had not loved us as God does, and of a kind that Thomas disparages. In sacred doctrine at least, since it considers all things precisely as ordered to God, nature cannot appropriately be defined apart 
from grace. Grace does not however for that reason get defined in terms of nature. Rather for that very reason grace remains independent of nature, just because nature could not exercise any independent causality over against grace. The only causality that operates toward God is the causality by which God, working either within or without the will, calls all creatures according to their natures into the divine communion. Barth makes that move too, when he interprets creation as the "external ground of the covenant," and the covenant as the "internal ground of creation." ${ }^{50}$

Hunsinger would presumably press his point. He would say that the very language of "capacity" and "openness" surreptitiously defines not only nature but grace too. He could appeal to the logic of question and answer in his reply.

The rejoinder to the point pressed makes both a concession and a demurrer. It is true that language works in a way that constrains answers, to some extent, in terms of the questions. Human beings first understand the gospel stories in time, for example, because they have learned language from their human parents. But that does not mean that the truth of the gospel stories or the significance of the concepts they convey depend logically upon how they have learned certain truths or concepts. Rather Thomas would say that the truths or concepts that come to them inherited logically owe their truth or helpfulness to their participation in the first truth. Thus the fact that language makes the semantic range of words like "capability" and "openness" depend both upon what is open and what it is open to does not mean that the facts arrange themselves that way.

Second, Thomas would defend the sense of "capax" as entirely negative. Hunsinger's qualification "as used by Aquinas" undermines his case: the case fares better with the qualification "as read by others." Thomas denies that nature is capable of grace in the sense Hunsinger rightly fears, that of finitum capax infiniti, or the finite capable of the infinite. Rather Thomas regards nature as capable of grace in the sense of God's plan to save that which God created, or to carry through what God had begun. It is none other than God's own purpose that God saves. Thomas adduces a quotation from Augustine to clarify the remark in just that way. "Naturally the soul is open to grace" gets glossed as "is open to God by grace." Nature is only open to grace by grace.

Hunsinger surreptitiously assumes that nature could be open to grace only by itself, since "graced nature" seems like a contradiction in terms to many Protestants. But it does not to Thomas. Grace clears its own room. The word seeks to exclude the violence to nature that Barth also wants to exclude. But the misunderstanding, as we have seen, goes so deep as to need a reconceptualization. I shall propose two.

1. Hunsinger grants a concession earlier on the same page. It does not go far enough. Better, it goes back and forth — all the more reason for a reconceptualization. It says: "Although human freedom is certainly [in Thomas] in some sense conceptually subsequent to and dependent on divine grace, in another (if perhaps secondary) sense divine grace is nonetheless subsequent to 
and dependent on human freedom. By contrast, as previously suggested, Barth's position on such matters is always one which repudiates a scheme of conceptual interdependence in favor of a scheme in which divine grace cannot be understood except as conceptually prior to and entirely independent of human freedom." Hunsinger might better have written not "by contrast," but rather "in a similar way." The "other, secondary sense" in which for Thomas divine grace is conceptually subsequent to and dependent on human freedom is just another way in which Thomas reverses the usual polarities of conceptions so that the aspects of human freedom on which grace seems to depend (the usual suspects of the theology of controversy)-like cooperation, merit, preparation, perseverance, reason-become so many ways in which Thomas takes an apparent pretension to human autonomy, analyses it, and finds grace. The language of subsequence and dependence tends finally to break down. For as long as the language of divine and human "agency" is in place it becomes difficult to teep up the task of conceiving of them as on two different levels. Yet everyone would insist, whether via an analogy of being or via an analogy of faith, on the distinction, because thinking of them as on two different levels keeps getting undermined by thinking of them as two levels of the same sort ofthing. We do not want to give up the double language of agency-Hunsinger makes it, in a final chapter, his test casebut we misread Thomas if we do not notice how at every opportunity he puts up roadblocks against the conclusion that in comparing divine and human agency we have two levels of the same sort of thing. Take merit-talk as an example. "Merit" gets defined as if the dishes of a balance that would weigh us became buckets to uplift us (I-II.114). I take the images from George Herbert, whom I find almost perfectly to represent, willy-nilly, Thomas's integration of the biblical merit-talk into a sola gratia scheme:

Justice [II]

The dishes of thy balance seem to gape

Like two great pits;

The beam and scape

Did like some torturing engine show;

Thy hand above did burn and glow,

Daunting the stoutest hearts, and proudest wits.

But now that Christ's pure veil presents the sight,

I see no fears:

Thy hand is white,

Thy scales like buckets, which attend 
And interchangeably descend,

Lifting to heaven from this well of tears.

Thomas too practices such reversals at every turn.

It is more helpful to think of Thomas as treating the will as a place where God also works. Protestants tend to think of the will as a God-forsaken place. Thomas thinks of the will as another locus of divine activity. Better: "the will" is the name for the place where God primarily addresses, engages, and involves human beings. "The will" is also the name for the place where human beings primarily rebel against God. For that very reason God's activity in that place, God's taking that field, salvation's occurrence and working out just there can only be the work of grace alone. Thus the dense and elegant formulation of Bernard of Clairvaux: "The entire work is in the will precisely because the entire work is from grace." ${ }^{51}$

2. Imagine the nature-grace debate as a debate about what class of stories in the gospel to use to explicate the question of what it means to "hear" the word of God. Take Protestants as tending to imagine it this way. There are two candidates: the parables and the healings. ${ }^{52}$ In the parables it is assumed (except perhaps in Mark) that human beings have an innate capacity to hear and understand: The one who has ears to hear, let that one hear. So it makes sense to talk about a human faculty, analogous to hearing, that takes in the word of God, a capacity for grace. That, Protestants take it, is the Catholic view.

But that view, imagine our Protestant continuing, is too optimistic. It does not take account of the stories in which the hearers notoriously fail to understand, and of the version in which Mark says $(4: 12)$ that Jesus speaks in parables in order that the hearers will not understand. Mention is made of human capacity only to emphasize human incapacity. Mention is made of public parable only to emphasize the private explanations to the disciples, so as to preserve divine freedom with regard to who understands and who does not. So the parable model of human response to God's word, or, if you like, of the human cognition of God, breaks down. Better to turn to another.

Take the Protestants, then, to see themselves as preferring a second model, that of the healing stories. Protestants want to emphasize the reversal by which it is none other than the blind who see, the deaf who hear, the lame who leap for joy. Similarly in Mark it is never the disciples, even with their parable explanations, who are said in the indicative mood to "follow Jesus": they are only commanded to do so, in the imperative, especially when like Peter they stray: "Follow after me, Satan." It is not until the episode after Jesus's sharp rebuke of Peter that Mark comes to say (10:52) of the healed Bartimaeus alone (the one whom Jesus had found blind and screaming by the side of the road), simply and without qualification, in the indicative rather than the imperative mode: "and he followed him." ${ }^{53}$ It is those stories, the Protestant would say, to which we ought to turn to see what human capacities are like. There are none. The gospels describe them as incapacities: as blindnesses, deafnesses, lamenesses. They wait upon a miracle also in the second sense of the typology of miracles that Hunsinger quoted from Thomas above. To 
explicate blindness, deafness, and lameness as "openness and capability" flies in their face. The gospel knows eyes closed, ears stopped, legs crippled. Far better to take Barth's tack: that possibility follows from actuality. Better to talk about the sight of the sighted than of the "sight" of the blind. The latter is what we have seen Thomas up to in the Romans commentary: talking about the "cognition" of the ignorant.

That, I take it, explicates a certain sort of Protestant argument so far.

Thomas has a rejoinder. First he would observe that it cannot be wrong to speak of things that we cannot understand. The blind, the deaf, the lame are still defined, on the level of biblical language, in terms of the capacities they lack, even if it does, as everyone admits, take grace to restore them. When we hear about the "ears of the deaf unstopped, the eyes of the blind opened," it is indeed ears and eyes that they possess, their own nature restored. ${ }^{54}$ If we outlawed all talk of nature — of eyes and ears and legs_—we might misread the biblical healing stories as contrary to nature, as "bestowing" upon us unhuman capacities that could only violate us. Thomas is afraid that in the absence of nature-talk the healing stories would look as if Jesus had bestowed upon human beings not their own nature in return but faculties alien to them: not sight but radar, not ears but antennae, not two good legs but six. Absent talk of nature, Thomas might fear, it becomes hard to distinguish metanoia from metamorphosis, the gospels from Kafka. It is the absurdity of grace's turning human beings into cockroaches, and not its independence, that Thomas wants to deny when he says that the human soul is open to grace "naturaliter."

We can even say something about the positive point of Thomas's talk about human faculties in terms of these stories. The characters in the gospel healing stories remain, by God's prevenient mercy, able to use the words that form a request for healing even as they remain also unacquainted with the state that they request. The presence of Jesus prompts the blind to ask for sight even without having experienced it. So there seems to be a place for talk, for linguistic place-holders, even where we do not have discursive intelligibility of the quid est to which we refer.

The full integrity of this talk depends, to be sure, upon its coming from a person who enjoys effective use of the faculty mentioned. Similarly the full integrity of the cognition of God depends upon the propositions inhering in a mind united by faith with the first truth, and in that case the cognition is effective in the soul (is formed faith). But language retains a residual sense just when we know the use of the words. (Most human language proceeds in this mode, which is why Wittgenstein is helpful.) It retains that residual sense not because truth inheres in words and propositions, but because the usage in the community is not entirely divorced from the reality wherein the truth inheres. The requests of the gospel blind, deaf, and lame to be healed make sense because the sighted, hearing, and walking keep those words alive and in contact with the form of life in which they enjoy their full integrity. Similarly, talk of the knowledge of God proceeds not because the cognition inheres in the propositions, or even, finally, because even one human being could, over a long period of time, reach some truth about God, and keep the 
community in touch with reality, but rather because God does not abandon us utterly. That God does not abandon us utterly means just that God mercifully preserves our nature from entire nonexistence. God preserves some community with us, even that of God's wrath (Vulgate: ira) which Thomas glosses as God's vindicta, vindication, or God's desire for self-justification In Rom.l:18, \#110) as the promising God (In Rom.l:17, \#102)—that we encounter the cognition of God that human beings have "by nature." It is certainly not in virtue of something independently human - which if not meaningless would have to mean that which refuses, against nature, to depend upon grace, and that which therefore blinds, deafens, lames, and kills - that God, according to Thomas, preserves eyes, ears, legs, and lives. It could not be, as hyper-Protestants claim, that Thomas has God preserve nature in virtue of anything other than its utter dependence upon grace. It is in virtue of nothing other than God's plan that in the meantime we retain only miraculously usable eyes, ears, legs, and lives. God preserves the blind for no other reason than that they may see, the deaf that they may hear, the lame that they may leap for joy: in the same way God preserves nature denatured to be restored and elevated, cognition dead that as faith it may live and have life abundantly. That is the pattern that Thomas seeks positively to preserve.

"Mainly, [Barth] believes, grace would not be grace-it would not be sovereign, free, gratuitous - if human freedom were not conceptually subsequent to and entirely dependent on it," Hunsinger concludes. Thomas believes that too, without qualification. Human openness to salvation, expressed either as Unfällen reason or as willing cooperation, belongs on the side not of our contribution to a redemption from a sin wherein we cannot help ourselves, which is for Thomas too a contradiction in terms, but on the side of the persistent mercifulness toward us and faithfulness ad intra of God in the divine plan, a plan to elevate this creature, the very one whom God created open to friendship with God, and the very one that rebelled against it. It is the blind who see, the deaf who hear, the lame who leap.

So far the Barthians.

2. Assessment and significance of the hypothesis: Thomas and Barth in convergence on Romans 1 ?

Let us pursue the comparison with a return to the Shorter Commentary. I confine myself to Barth's comments on 1:18-32, some six pages. I regard them as parallel to longer discussions in the Dogmatics. Their brevity, their commentary-order and their commentary-context, parallel to Thomas's, give those comments great advantages for my purpose over the comments of the Dogmatics, without loss. ${ }^{55}$

Barth begins with a paragraph of rhetorical questions that he then devotes half the exposition, some three pages, to answering in the negative:

Does Paul mean a second or even a first revelation apart from the one mentioned in 1.17 when now he suddenly introduces a revelation of God's wrath against all the ungodliness (irreverence) and iniquity (insubordination) of human beings, viz. of the Gentiles (1.18-32) and the Jews (2.1- 
3.20)? Has he abandoned his office as a messenger of the Gospel for a while in order to speak in the first place in an entirely different capacity as a religious interpreter of the human situation as such, as a Christian student of the philosophy of religion and of history? This section has often been interpreted as if this were the case. Then that whole rather long section 1.18-3.20 would mean that Paul—as bad preachers are admittedly in the habit of doing —is leading off with a lengthy discussion of something quite different from his text, i.e. from the matter which he has already indicated clearly and unmistakably. Can we regard him as capable of that? ${ }^{56}$

The practiced reader of Barth will gather from the tenor of those questions the tenor of the answer, just as the practiced reader of Thomas's articles will be able to predict a lot about the respondeo from the objections. That Barth will reassert Paul's office as an apostle and his standpoint as one who confronts the Gentiles with the gospel of Jesus Christ (p. 27) is almost obvious. What is not obvious is why Barth perpetrates just the same sort of misreading against Thomas as he ridicules in readers of Paul. Thomas's advocates and detractors, Barth chief among the latter, act as if Thomas had "abandoned his office as a messenger of the gospel for a while in order to speak in the first place as a religious interpreter of the human situation as such, as a Christian student of the philosophy of religion and of history." We have seen that the description applies no more to Thomas than it does to Paul. That is also true for many of the same reasons. In fact we may take Barth's defense of Paul to apply tout court to the proffered reading of Thomas. The overall shape of Barth's argument fits.

A number of particular features stand out.

1. Barth like Thomas makes God's wrath a form of God's grace. For Thomas God's ira is God's vindicta, at once the self-justification by which God maintains the integrity of God's promises and the deliverance according to which God carries out the divine intention in creation (In Rom.l:17-18, esp. \#\#102 and 109). From Barth, similarly, we learn that Paul "sees the Gentiles as well as the Jews in the reflected light of that fire of God's wrath which is the fire of [God's] love," and that that love has endured "for a long time, yea always, since the creation of the world" (p. 28).

2. Barth like Thomas sees Paul as ascribing a knowledge of God to the Gentiles (whatever its status) in order to stake out as it were a certain field. Thomas wants to render all true human cognition incorporable into sacred doctrine, wants to treat all things as revelabilia (ST 1.1.3) and so to leave no realm God-forsaken. We could take Thomas therefore to be proposing the natural cognition of God to be an answer precisely to this question of Barth's: "How can the Gospel be God's almighty power (1.16), if the Gentiles could exculpate themselves by saying that God is a stranger to them, that they are living in some forgotten corner of the world, where God is not God or cannot be known as God ...?" (pp. 28-29). Both Thomas (In Rom. 1:20a, \#115) and Barth want to deny that question's presupposition. Yet it is in providing an articulation of that denial that Thomas's concept of concrete nature, nature always already shot through with grace, finds its point and purpose. It is a nature from which God has never entirely withdrawn the grace 
intended to elevate it, sustaining the creation, and here appearing as God's wrath: This nature is the "place" in which the Gentiles live, in which it would be as false for Thomas as for Barth to say that "they are living in some forgotten corner of the world, where God is not God or cannot be known as God." That is the sense in which nature is graced, in which God refuses to leave us alone. Barth imagines that that nature or place is otherwise for Thomas; he continues to ask, expecting a negative answer, "if there were such a thing as a self-contained Gentile world, established, secure and justified in itself" (p. 29). But Thomas's concrete nature is precisely not self-contained, precisely not "established, secure and justified in itself." To have security ("fiducia") in ourselves and "ascribe good," or justify ourselves is for Thomas too precisely our Gentile sin (In Rom. 1:21, \#129). Rather concrete nature is contained in grace, established in grace, and first secure and justified in grace, even if that grace first appears as God's delivering vindication. Barth's denial of such a Gentile world, a God-forsaken one, is the affirmation of a natural world, when we understand "nature" as Thomas does. It is the world in which, Barth and Thomas would agree, God's grace blows as wrath (vindicta Dei). And it is the same world in which, Barth and Thomas would agree, God's grace blows as gospel ("evangelica gratia" In Rom. 1:16, \#97-99, which is of Christ, \#102). One world, one grace. Barth defines that world negatively as one unforgotten by the grace of Christ; Thomas defines that world positively as one where the grace of Christ is necessary and sufficient (\#109); so that even the positive definition belongs in the inalienable context of grace, and has never, in fact, existed for its own sake.

3. Barth like Thomas is able, when it suits him, to distinguish between effective and ineffective cognitions of God-and even to preserve the word "knowledge" or "Erkenntnis" for the latter. "In spite of their objective know-ledge of $\operatorname{God}^{57}$ they have not rendered to [God] the honor and gratitude they owe ..." (p. 29). Usually Barth reserves Erkenntnis for knowledge as a concrete formation of the soul, complete with obedience (Gehorsamkeit) and thankfulness (Dankbarkeit) much as Thomas reserves cognitio vera for the form that "leads human beings toward the good" (In Rom. 1:18, \#112), which Thomas tends in the Romans commentary to follow Paul in identifying with justice (\#112) and gratitude (e.g., In Rom. 1:8, \#75; 1:21, \#127); that is how it works in the Church Dogmatics too. But here, evidently, he is open to Thomas's way of dividing things up, and he finds it useful, perhaps even necessary, to resort to it, precisely in order to do justice to the usage of Paul. And that openness - so rare for Barth to assert, so difficult for Barth to give an account of - is just the place where Thomas anticipates the need of an articulate account and seeks, in the service of explicating precisely the necessity and efficacy and power of what he calls gratia evangelica, to supply one.

4. Thomas like Barth insists that, as Barth puts it, "Paul does not dream of paying the Gentiles anything resembling a compliment and of trying to find in their religions some point of contact for the understanding of the Gospel; on the contrary he is merely and simply calling them to faith in God's verdict" (p. 28). That is the reason why Thomas can turn around and characterize

the cognition he has so carefully accounted for as one that effectively the Gentiles lack, because it paradoxically manages to leave them unformed. As Preller puts it, "Such 'cognition' of God 
that philosophy can produce is merely the clarification of what was there all the time- $-\mathrm{a}$ felt ignorance/ ${ }^{58}$ That is why Thomas insists on accounting for human natural cognition of God in its full, salvific, graced rather than residual and defective form, why he describes it in Paul himself as involving "all virtues," as specified by charity (Proh,\#1), and why he describes it even at Romans 1:20 as objectively trinitarian, whether the Gentiles recognize it as such or not (\#120): so that he has a contrast by which to render the Gentiles' relative cognition defective and their relative ignorance culpable $\{$ In Rom. 1:21, \#127).

5. Thomas like Barth insists that this culpability leaves the Gentiles in a situation from which they cannot free themselves. "[Paul] starts by referring to the best the Gentiles have, or claim to have: their religion, which consists in one great confusion between the Creator and [the Creator's] creatures. If there is any position from which no bridge can possibly be built to the Gospel, to the knowledge of the living God, then this is it! Human religion, as radically distinguished from belief in God's revelation, always originates and consists in this confusion: in the mistaken confidence in which [human beings] want to decide for [themselves] who and what God is, which can only produce this confusion, i.e. idolatry. This mistaken self-confidence is the actual object of God's wrath." The contrast Thomas makes, parallel to Barth's, is the one he describes when he writes, "In their thoughts they became empty, in so far as they had trust [fiducial] in themselves, and not in God" (In Rom. 1:21, \#129) and when he says "For the Apostle appears ... to touch ... natural theology, which the philosophers in the world observe, worshiping parts of the world, and with respect to this he says: And they worshipped and served the creature rather than the Creator" (\#149 in fin.). For the natural cognition of God is neutral only when Thomas considers it in abstraction from the mind that holds it, and since Thomas, unlike the twentieth century, defines truth not in terms of propositions but in terms of the adequation of a thing to the mind, that is a fairly odd thing to do. In actual human minds Thomas evaluates the knowledge of God according to what use the human being puts it, which is to say the will, and there all the language of praise and blame is at home. ${ }^{59}$ So Paul could "pay the Gentiles a compliment" only with regard to their use of their knowledge; but they use it ill, "subtracting from God's power and scientia ... but rather they ascribed their good things to their own ingenuity and power ... the light of wisdom having been taken away" (In Rom. 1:21, \#\#127,129,130).

6. Both Barth and Thomas want to talk about a refusal of God to abandon human beings, which Thomas explicates with the concept of nature and Barth explicates with his talk of a world unforgotten, as well as about a delivering up of human beings to their own sinful desires. Thomas can make the distinction as one between the will that sin affects directly (the delivering up) and the relatively upright powers of reason that sin affects indirectly (the leaving unabandoned) in every concrete human being. Barth replaces distinction with dialectic, so that talk of God's not abandoning the Gentiles to any place where God is not God gets juxtaposed with talk of God's abandoning the Gentiles to their own desires. That dialectic is saved from contradiction just if we read it in Thomas's terms: the place where God does not abandon them is 
the place God's grace sustains for them in their concrete nature, and by the grace of God it is in just that God-sustained place that their falling down occurs.

7. Barth like Thomas insists that "human beings are without excuse, because, having the knowledge of God, they still do not render [God] honour and thanks as God. It is unquestionable that knowledge of God is here ascribed to the human being in the cosmos, and knowability is ascribed to God" (CD II/l, p. 119, translation slightly modified). Of course this knowledge, in Barth as in Thomas, is no independent knowledge, but depends, for Barth, upon the "revelation of the grace of God in Jesus Christ," as for Thomas upon the evangelica gratia Christi. And for Thomas as for Barth it proves effective only as that knowledge is "fundamentally surpassed, but at the same time also included, in a higher knowledge, and, despite its limitation, raised into this higher knowledge" (CD II/l, p. 116)—much as for Thomas too the natural cognition of God is taken up into sacred doctrine by the technical means of parsing it as revelabile or subordinating it to the primary demonstration in the humanity of Jesus Christ.

8. Both Barth and Thomas want to affirm that what God primarily reveals is God's own self in Jesus Christ. For Barth Jesus Christ is the primary form of the threefold Word of God, incarnate, written, and preached. For Thomas Jesus Christ must also be the real, light-giving aspect of the Revelation in order to ground the new scientia of sacred doctrine as other revelations grant to other Aristotelian disciplines the first principles that give them rise. According to the Summa's account of "proceeding from first principles," sacred doctrine is not a deficient science for proceeding from Revelation: it is rather for that very reason a proper science; indeed, it is science par excellence. To proceed from first principles means, in the Summa's version of Aristotle, to proceed from formal "revelations." All science arises from small-"r" revelations; sacred doctrine too arises from a revelation; therefore sacred doctrine counts as science, even science par excellence. ${ }^{60}$ For both Barth and Thomas scripture is the place from which one mounts arguments, for Barth as the second form of the Word of God, for Thomas as the proposi-tional form of the first principles to which sacred doctrine must attend and return in order to exercise its scientific character. And for both Barth and Thomas the scripture witnesses, whether as the Word's secondary form, or as scientia's propositional aspect, to Jesus Christ as the argument that trumps or absorbs all others. True human words from the secular sphere "are true in their supposed and implied, if not always immediately apparent, connection with the totality of Jesus Christ and his prophecy, and therefore as they indirectly point to this, or as this indirectly declares itself in them" (CD TV/3, p. 123). ${ }^{61}$ That statement could well serve as a summary of the move that Thomas makes in articulating sacred doctrine's overarching unity and integrity in question 1, or in construing cognitio naturalis in the context of God's delivering wrath and the gospel grace of Christ in Romans 1.

This is all by no means to deny that large and important differences remain between Thomas and Barth. But it is to say that they are differences that distinguish different human beings on the side of the angels, rather than one on the side of the angels and one on the side of the Antichrist. To find Thomas and Barth in convergence in their commentaries on Romans-not just on any book, 
but on Romans - is to find them in convergence in the place where for both the Summa and the Dogmatics the account of the natural knowledge of God is at home. It should dispense, too, with many objections that Protestants may still harbor toward that account. "Spitzenleistung/' indeed!

The account raises new objections, to be sure. To explain how both students of Barth and students of Thomas came to agree on their divergence would require an account of how both Barth and Vatican I represented opposing responses to Kant. That is a topic for another day. ${ }^{62}$

\section{NOTES}

1 Thomas Aquinas and Karl Barth: Sacred Doctrine and the Natural Knowledge of God (Notre Dame, Indiana: Univ of Notre Dame Press, forthcoming). This article corresponds to much of what will be chapter 7 with bits from chapter 6 and elsewhere.

2 Karl Barth, Kurze Erzählung des Ròmerbriefes (Munich: Christian Kaiser, 1956); ET, A Shorter Commentary on Romans, no translator (Richmond, Virginia: John Knox, 1959). Note that the Shorter Commentary is not a version of Barth's hermeneutical manifesto, Der Rómerbrief (The Epistle to the Romans) of the teens and twenties, but an entirely different work very close in content to parallel passages in the Dogmatics.

3 Text and paragraph numbering follow the Marietti edition: Super epístolas S. Pauli lectura, 2 vols., 8th rev. ed., ed. Raphael Cai, O.P. (Turin and Rome: Marietti, 1953), vol. I. The prologus and Romans commentary appear in vol. I, 1-230. I will cite them in the text by Prologue or "In" (for "In Romanos") chapter and verse, plus the Marietti paragraph number. The translation is mine, and may vary according to the uses to which I put it. An English translation is being prepared by Steven C. Boguslawski. The typography also follows the Marietti edition, and requires a little explanation. Thomas's text appears in plain Roman type. Section numbers added by Marietti and the text of the verse currently being commented upon appear in boldface Roman type. Thomas's quotations from the Bible and others appear without quotation marks in italic type. (In general, that has the advantage of causing the structure of Thomas's citation of authority, especially scriptural authority, to stand out.) Biblical verse numbers added by the Marietti editors appear here as there in the text without square brackets to segregate them. Other sources identified in the Marietti notes I have moved into square brackets within the text.

4 In Thomas and Barth, Part I supplies plausibility for the reading to follow of Thomas on Romans by showing what scripturalist and christoform resources exist in-or more strongly, govern - the methodological reflections of the Summa.

5 In the book I execute a fairly long and very close reading of Thomas's commentary on Romans 1 in defense of the theses here asserted.

6 In the book, an Epilogue speculates about why students of Thomas and Barth have almost universally failed to see it 
7 Karl Barth, Fides quaerens intellectum Anselms Beweis der Existenz Gottes (Munich Christian Kaiser, 1931), and m English, Anselm Fides Quaerens Intellectum Anselm's Proof of the Existence of God in the Context of his Theological Scheme, trans Ian W Robertson (Richmond, Virginia John Knox, 1960)

8 Michel Corbm, Le chemin de la théologie chez Thomas d'Aquin, Bibliothèque des archives de philosophie, nouvelle série, 16 (Pans Beauchesne, 1974), pp 698, 718, 763, 838

9 I confine my claims to the versions m the Summa theologiae and the In Romanos I distinguish the project of the Contra gentiles below

10 Karl Barth, Die Kirchliche Dogmahk, 4 vols m 12 parts (Zurich Zollikon, 1932ff ) ET Church Dogmatics, ed and trans G W Bromiley and T F Torrance (Edmburgh T \& T Clark, 1936ff,2ded of vol 1/1,1975) Here, vol II, parti, $\rho 127$, translation modified Heremafter cited like this CD $11 / 1, \rho 127$

$11 C D \Pi / 1, \rho 82$, emphasis added

12 A Late Friendship The Letters of Karl Barth and Carl Zuckmayer, trans Geoffrey Bromiley (Grand Rapids Eerdmans, 1982), $\rho 42$ Barth dates the letter 7 May 1968 German Gesammtausgabe Briefe, V, $\rho 286$, \#286

13 "Scientia naturalis res a Deo procedentes considérât" (In John, prol, \#9) I adopt the translation of James Weisheipl, trans and ed, Commentary on the Gospel of St John (Albany Magi, 1980), $\rho$ 26 , $\mathrm{m}$ which the crucial "as" is perhaps tendentious In any case I adduce the quotation as illustrative and suggestive

$14 \rho 28$, emphasis added

15 I mimic the phrase, modified from a technical term of different range comed by Wilfred Sellers, that appears at the end of Victor Preller, Divine Science and the Science of God A Reformulation of Thomas Aquinas (Prmceton, 1967) "the material moves of faith," pp 266-73

16 The "Paul" m question may or may not differ from the "Paul" delivered by historical criticism, I mean a figure with enough $\mathrm{m}$ common with the traditional readmg that both Thomas and Barth would recognize an appeal to him as authoritative and potentially challenging

17 For a Wittgensteinian account of how texts and interpreters influence traditions, see Kathryn Tanner, "Theology and the Plam Sense," m Garrett Green, ed, Scriptural Authority and Narrative Interpretation (Philadelphia Fortress, 1987), pp 59-78

18 In Rom 1 25, \#145 and ST II-II94 1, both times quotmg Augustine, De civ Dei 75

19 I owe the contrast "logic of commg to believe/logic of belief" to Hans Frei 
20 Etienne Gilson, The Christian Philosophy of St Thomas Aquinas, trans L K Shook (New York Random House, 1956), $\rho 9$ The passage is quoted and discussed $m$ Bruce D Marshall, "Aquinas as a Postliberal Theologian," The Thomist 53 (1989), pp 389-90

21 \#115, which the Marietti edition assigns to 119, although the three arguments ("per causalitatem" "per viam excellentiae," and "per viam negahonis") correspond explicitly (\#117 in fin ) to the virtus, divinitas, and invisibilia of 1 20a By "cosmological" (not Thomas's term) I merely mean not ontological and not transcendental, 1 e, his arguments, not Anselm's or Schleiermacher's

22 For an elegant summary of the rise of the genre of the Summa from that of commentary, recapitulating the career of the magister in sacris paginis, see Alasdair Maclntyre, Three Rival Versions of Moral Enquiry Encyclopedia, Genealogy, and Tradition (Notre Dame Univ of Notre Dame Press, 1990), pp 84-85

23 Thomas's fiducia, In Rom 1 21, \#129

24 Justice and piety In Rom 118, \#111, gratitude, 1 21, \#127, charity (as forming faith), 117, \#\#106-108, m Paul as exemplar (on which see Thomas and Barth, chapter 3), prologue, \#1

25 Who counts as a Gentile is a fluid issue, because once the definition of "non-Jew" is left behmd, the concept behaves with the uncertainty of "the apparently unsaved," the identities of whom are not susceptible to human discovery Cf П-П 2 7, П-II10 6 As Preller restates those passages, "We cannot, then, know that we have truly informed faith - that there is m our 'souls' mat intentional image of God which conforms us to [God] There is no more $m$ the conscious mind of the true believer than may be present $\mathrm{m}$ the conscious mind of the nonbeliever ... it is quite possible that God ... has 'seized' the will and affections of [human beings] who-for one reason or another-do not assert the truth of the propositions of faith" (p. 265). I hope to sort out Thomas's uses of "Gentile," with special attention to his commentary on Romans 9-11, in a future article.

26 The whole epistle from 1:16b to 12:1, according to Thomas, is about the "evangelica gratia" (\#97) that he constantly ascribes to Christ, especially in the Prologus to the epistles.

27 The diachronic reading of Thomas, which distinguishes the project of the Contra gentiles fairly sharply from that of the Summa theologiae depends on Corbin, Le chemin.He devotes a couple of hundred pages each to the methodological parts of Thomas's great treatments of theology: the Sentences, the In Boethium de trinitate, the Contra gentiles, and the Summa theologiae. The argument in this article, therefore, is limited to the last Summa and its period, from which the Romans commentary also dates. For textual and exegetical support of the interpretation of the Contra gentiles, see Corbin, esp. pp. 643-91, and Thomas and Barth, chapter 1 and the excursus to chapter 6 . 
28 In Rom.l:20a, \#122 read in conjunction with \#\#115 and 117. For argument see Thomas and Barth, chapter 5.

29 Otto Hermann Pesch, Die Theologie der Rechtfertigung bei Martin Luther und Thomas von Aquin, (Mainz: Matthias-Grünewald, 1967), p. 489. For the first clause he cites CG IV.52, In Rom. 5:12 (\#416), De malo 4.2 ad 1, and ST I.-II.85.1, and for the second ST I.95.1c, 1.100.1c, De malo 4t, le ca. med., 4.4 ad 1,4.8c, 5.1c and CG IV.52.

30 1.100.1c and ad 2. The rational soul is not passed on "naturally," but is "conferred" by God.

31 Pesch, Rechtfertigung, p. 491, material in brackets from p. 490.

32 For Paul as exemplar of graced nature, see Thomas and Barth, chapter 3.

33 The word "detenta" comes in the Vulgate of Rom. 1:18, which Thomas comments on at \#\#111-112 and again at In Rom. 1:21, \#127-130.

34 For more, see Thomas and Barth, chapter 7.

35 Rechtfertigung, p. 526. The paragraph concludes a section called "Natur und Gnade," under the chapter title "Macht und Ohnmacht der Sünde."

36 For textual and exegetical support of this interpretation, see Corbin, pp. 741-43.

37 ST 1.46.2; cf. also De potentia q. 4, a. 1, c, post init.

38 According to Preller. See pp. 22-25 (in general) and 108-178 (in detail).

39 It is the burden of the last section of chapter 2 of Thomas and Barth that Thomas's various uses of words like demonstratio and demonstrare, and synonymous instances of via, conform to the technical definition of analogy, so that Aristotelian demonstration becomes a secondary and subordinate analogate of the primary analogate, which is the demonstration of the Father by the Son ("demonstratio Patris," ST 1.42.6 ad 2). I argue there that the general rule covering many cases - the syllogistic, the ostensively identifying, the miraculous, the sacramental, and the semantically identifying — is that "a word comes between the one demonstrating and what the demonstration is of [verbo est inter demonstrantem et cui fit demonstratio]" (In John 5:20a, \#754). If so, then programmatic remarks like those in the proemium to ST 1.2 and the prologue to ST III can carry more freight than they usually do: "[Christus], secundum quod homo, via est nobis tendendi in Deum" and "Salvator noster Dominus Iesus Christus ... viam veritatis nobis in seipso demonstravit." (I owe my attention to the latter to Alasdair Maclntyre.) On this topic see also Preller, p. 253, and Michel Corbin, "La Parole devenue chair (lecture de la $V^{e}$ question de la Tertia Pars de la Somme Théologique de Thomas d'Aquin)," chapter 3 in L'inouï de Dieu: Six études christologiques (Paris: Desclée de Brouwer, 1980), pp. 109-58. 
40 Among them is also a scientia "under the conditions that faith requires" (П-П.2.2 ad 3) that "adds to the merit of believing" (II-II.2.10). How that works forms the subject of a long excursus to chapter 6 in Thomas and Barth. See also Bruce Marshall, "Aquinas as a Postliberal Theologian," The Thomist 53 (1989) pp. 353-402, and the discussion in The Thomist, vol. 56.

41 That is the thesis of Thomas and Barth, chapter 2.

42 Here follows in Thomas and Barth a long excursus about Thomas's threefold division of faith in both the Romans commentary (In Rom. 4:3, \#327), and ST II-II.2.2. It concludes with three additional theses:

Cognitio Dei is neutralized without credere Deo. That is, when trust is subtracted, the integral form cannot any longer form the soul or lead the will toward friendship with God.

Cognitio Dei is falsified without credere in Deum. That is, when love is subtracted, a person's actions belie her well-formed statements.

Cognitio Dei is diversified in the presence of an Aristotelian demonstration. That is, when faith in a particular proposition is subtracted, the focus of faith narrows to what is more central to its friendship with God, without any change in faith's act.

43 As I argue at length in Part I of Thomas and Barth.

44 For the argument on the technical workings of this claim in Thomas, see Thomas and Barth, last section of chapter 2. For a similar analysis of Barth, see Bruce McCormack, Karl Barth's Critically Realistic Dialectical Theology: Its Genesis and Development, 1909-1936 (Oxford: Clarendon, 1995), Chapter 8, pp. 327-74.

45 For more on this fourfold division of scientia, see chapter 2 of Thomas and Barth.

46 Thomas and Barth, chapters 3-6.

47 See Corbin, Le chemin, eh. Ill, section IV: "Le passage de la Somme contre les gentils à la Somme théologique (livres II et IV)," pp. 643-92, and on the relation of the project of the Summa Theologiae to the project of the Contra gentiles as a whole, pp. 705, 713, 741, 745, 759-60, 79899, et al

48 George Hunsinger, How to Read Karl Barth: The Shape of His Theology (Oxford, 1991). I have otherwise the greatest admiration for the book, especially for the Epilogue (pp. 234-80) on Barth's views of the relation between truth and Christ, which reminds me a great deal, mutatis mutandis, of Thomas. The quotations that follow all come from p. 146.

49 I owe the word "non-critter," used of God, to Robert Gregg.

50 CD III. 
51 Bernard of Clairvaux, De gratia et Ubero arbitrio (PL 1027) quoted in Hans Kiing, Justification: The Doctrine of Karl Barth and a Catholic Reflection, 2d. ed. (Philadelphia: Westminster, 1981), p. 266; cf. Treatises (Washington: Cistercian, 1974), vol. 3, p. 106 , \#47.

52 My usage of the parable metaphor here is entirely different from the terminology of "secular parables" by Barth.

53 I owe my attention to the narrative significance of that sequence to Richard Hays.

54 I intend this account as a reformulation of Thomas, but he does use the same metaphor literally: "As neither were the eyes which Christ gave to the one born blind of another sort than the eyes that nature produced" (1.94.3 adi).

55 The closest parallel comes at Church Dogmatics 11/1, pp. 118-23, where even the wording is similar. Cf. also 1/2, pp. 304-307.

56 Barth, Shorter Commentary, p. 24, translation slightly modified. Thomas and Barth devotes chapter 3 to the identity of Paul in Thomas's Romans commentary.

57 Emphasis added. Cf. the fuller context cited above.

58 Preller, p. 29, n. 41.

59 Hunsinger (pp. 255-56) sums up Barth's objections to natural theology like this: It advances three "unfortunate things: falsifying abstractions, neutral generalizations, and nonexistent capacities." But in Thomas, I have been arguing, grace makes abstract nature concrete; the analysis of an act particularizes and evaluates generalizations so as to leave neutrality behind; and nonexistent capacities are spoken of only to follow Paul in something like the way that Barth himself attempts to do. Thomas affirms their nonexistence not in terms of simple absence, but in more complex terms of ineffectiveness and culpability—which is the point of their nonexistence.

60 That interpretation is the burden of chapter 2, sections 3 and 4. See also Corbin, Le chemin, pp. 717-18.

61 As quoted in Hunsinger, p. 264. The entire chapter, pp. 234-280, is quite an elegant account of that feature of Barth.

62 An Epilogue of Thomas and Barth tenders some speculations. 